\title{
MARRIAGE, MIGRATION, AND URBAN DEMOGRAPHIC STRUCTURE: A CASE FROM FRANCE IN THE BELLE EPOQUE
}

\section{Leslie Page Moch*}

Marriage is central to understanding historical populations and the family. Not only is marriage the event in the human life cycle which precipitates family formation, but also marriage patterns are the primary surface on which fertility levels are inscribed. Age at marriage and proportion married determine females' exposure to risk of pregnancy. Since Hajnal demonstrated the primacy of nuptiality patterns to demographic behavior in the West (1953), marriage has been central to definitions of the Western family (Hajnal, 1965; Laslett, 1977). Moreover, nuptiality patterns respond to economic and social change. In the past few years, this has been demonstrated by Braun's (1978) and Levine's (1977) studies of proletarianization and by studies linking such factors as occupation, sex ratios (Haines, 1979) and economic crises (Wrigley, 1971:158-161) to nuptiality. Changes in marriage age and proportion married also have been accepted as part of Europe's demographic transition along with changes in fertility

*The author received her Ph.D. in history from the University of Michigan in 1979, and is now assistant professor in the University of Texas at Arlington. The present essay expands upon earlier versions delivered at the 1979 meeting of the American Historical Association and the 1980 Newberry Library Family and Community History Colloquium. Dr. Moch would particularly like to thank the participants in the colloquium, Charles Tilly, Louise Tilly, Ronald Toby, and Mary Jo Maynes, for offering helpful comments on this article. and mortality (Tilly and Scott, 1978:91-96).

Marriage may also be central to understanding the relatively low fertility and high mortality of the European city in history. Indeed, patterns of marriage among urban people may tell us more about urban population structure than such factors as urban family composition, which does not vary radically from place to place (Anderson, 1972:220, 222; Katz, 1975:221; Moch, 1979:319). Some have suggested that the role of migrants may provide a key to urban populations because their presence is associated with low fertility and high mortality. Specifically, the tendency of migrants to be unmarried people has been singled out as a crucial matter. One explanation for low fertility hinges on observations such as those of John Knodel and Mary Jo Maynes that many migrant women were single servants and that they therefore depressed urban nuptiality and hence depressed urban fertility as well (Knodel and Maynes, 1976; Knodel, 1977). Allan Sharlin argues that the phenomenon of urban natural decrease likewise hinges on the fact that migrants were disproportionately single, and as a consequence unable to offset losses to their numbers by children. Sharlin summarizes current thinking about the role of migrants in urban populations by suggesting that the conventional wisdom that cities would suffer natural decrease without an influx of migrants reverses the 
causality of the link between urban demographic viability and migration. That is, it may be that migrants did not rescue the city from demographic decline by infusing urban areas with reproductive young people so much as they may have depressed urban demographic viability by contributing people who were less likely to marry and who, by consequence, were less likely to have children to compensate for deaths among their own numbers (Sharlin, 1978). I will borrow Allan Sharlin's term and call this the model of urban migration, an alternative to the model of natural decrease.

The urban migration model fits with a number of observations about European migrants. Young men often pioneered migration streams, and men and women migrated separately. The men, like Auvergnat masons in Paris and Cevenol miners in the coal fields of the Gard, served as laborers (see Ackerman, 1979:106; Corbin, 1975:177-221; Lamorisse, 1975:140 $149,200-212$ ). Women concentrated in domestic service (Chatelain, 1969). Moreover, traditions of circular migration often meant that migrants were temporary urban residents, even if they returned to the city year after year. The view of migrants as a disfavored urban group in terms of marriage, reproduction, and survival is not strictly new, particularly among French historians, for whom the hospital records of the old regime are an important source of information about population movements (e.g., Garden, 1970; LeRoy Ladurie, 1966:93-98). And the hospitals were filled with poor, ill, and dying migrants.

Recent work on the relationships between migrants in the city and urban patterns of nuptiality, fertility, and mortality is invaluable to a grasp of the social processes linking the migrant with city populations. As such, the model of urban migration improves immeasurably over a concentration on aggregate urban natural decrease, which simply places cities' natural decrease on the negative side of the scale and incoming migrants on the positive side. This model approaches the larger question of the migrants' role in urban society, a particularly important role in continental Europe between 1850 and the First World War, when unprecedented numbers of people left villages and small towns for the city. And the aggregated data on urban nuptiality, age structure, and servants in cities suggest that migration offers an adequate, if not complete explanation for urban demographic patterns.

Yet there are reasons to be cautious about this view of migrants' demographic behavior. Although single males often initiated migration streams, married men and their families subsequently settled in the city (Ackerman, 1979:106; Corbin, 1975:177-221). When textile mills offered employment to children and adolescents, families moved together to textile towns (Tilly, 1979:112; Anderson, 1971a:59). And servant women did not always return home or remain permanently single. Rather, evidence suggests that they were likely to marry and remain in the city as the nineteenth century progressed (McBride, 1976). Finally, the studies upon which the model of urban migration is based rest primarily upon data aggregated at the city level which do not distinguish between migrants and natives, so the demographic behavior of migrants is inferred from their status as servants, young journeymen, and soldiers. (The exception is Sharlin's figures for natural increase by citizenship category in early modern Frankfurt.)' Anderson observes that low

'These figures give strong support to the model of urban migration, because they show natural increase among citizens and natural decrease among non-citizens. The extent to which the citizenship 
nuptiality associated with domestic servants may be due in part to the middleclass populations they serve and that the two cannot be separated using aggregated marital status data (Anderson, 1976:72). Because this model rests on differential demographic behavior-particularly different marriage patterns-it is best investigated by a direct comparison of migrant and native nuptiality. This paper will make that comparison for the city of Nîmes, France at the beginning of the twentieth century. Then it will compare the patterns of nuptiality for three streams of migrants living in Nîmes.

\section{Nîmes}

Nîmes is well-suited to a study of migrants in the city because nearly half of its adolescent and adult population had been born outside the city in 1906, according to the census lists for that year. ${ }^{2}$ Like many urban areas of the period, Nîmes was characterized by low rates of marriage and fertility. "They hardly ever marry in Nîmes," mourned Dr. Elie Mazel in 1887 (Mazel:230). The good doctor's survey of the city's demographic trends revealed low rates of marriage and reproduction. In the period $1877-1886$, the marriage rate in Nîmes was lower than that of Paris,

categories exaggerate the migrant-native distinction is unknown; "citizenship meant permanent residence and an established position," and non-citizens were usually migrants, presumably the least successful as well as the temporary migrants. See Sharlin, 1978:130.

${ }^{2}$ This information and the data in the remainder of the paper for migrants' and natives' marital status and household position are from the 1906 manuscript census lists for the city of Nîmes. A 5 percent sample of households was taken. Children were categorized as migrants if they were born outside Nîmes and as natives if they were born in Nîmes, regardless of their parents' origins.
Lyon, or even of Marseille, "the town of the European continent reputed to be the last in terms of nuptiality (Mazel, 1887: 231)." Had Elie Mazel made the same calculations twenty-five years later, he would have been equally disappointed. The marriage rate had declined further, and there was one divorce for every 19 marriages. ${ }^{3}$

The birth rate had also declined in the last half of the nineteenth century. The number of births declined from about 1,900 per year in the 1850 s (when the population of Nimes was about 54,000 ) to only about 1,300 births per year after the turn of the century (when the population was over 80,000 ). The crude birth rate fell by half, from over 34 births per thousand in 1851 to 28 in the $1870 \mathrm{~s}, 20$ in the 1890 s, to 16 per thousand in 1906 . By then, the index of marital fertility was a low .307.4

The decline in fertility in Nîmes coincided with the transformation of the city from an industrial center to a regional transport and commerce center. The nine-

${ }^{3}$ There were 6.85 marriages per thousand in Nîmes in 1906 (Ville de Nîmes, 1904-1908).

'The index of marital fertility $I_{g}$ compares the total births to women of childbearing years with the number of births which would have resulted if married women had experienced the age-specific fertility rates of married Hutterite women. (See Coale, 1969:5.) The number of total legitimate births is taken from the état civil of Nimes; the age structure of the married female population is based on the census sample. Because the age structure of the married female population is based on a census sample, the approximate nature of the measure must be emphasized in this case. An accurate measure rests on (a) absence of sampling error, (b) correct age reporting in the census, and (c) correct coding of marital status. There are probably errors on all three counts. Flawless age reporting is not characteristic of any census, as both Allan Sharlin (1977:257) and Etienne van de Walle (1974:151-154) point out. For comments on the coding of marital status, see discussion in text, pp. 74-76. 
teenth century saw the de-industrialization of what had been an important silk producing town in the eighteenth century and a producer of shawls and hosiery in the nineteenth. Although the manufacturing of shoes and clothing employed many Nimois in 1900, it did not employ nearly the proportion of workers it had fifty or even twenty-five years earlier (Moch, 1979:55-56, 59). Little remained of the artisanal and familial organization of manufacturing. Instead, white collar and service work became important. Here, as elsewhere along the Mediterranean littoral, urbanization and industrialization did not go hand in hand (Dugrand, 1963:1). Nîmes became an important entrepôt of the Paris-Lyon-Marseille railroad line, the intersection of the lines which brought coal and other products from the Massif Central, wine from Languedoc, and imported goods from Marseille and Paris. After the phylloxera epidemic of the 1870 s the creation of the Midi's wine industry increased Nîmes' commercial importance. One result of the transformation of Nîmes' economy was to reduce drastically family and child employment. The Enquête industrielle of 1848 listed 40 percent of the shawl manufacture employees as children and 20 percent as women (Statistique générale, 1848: 70-76). Yet jobs for children disappeared in the last of the nineteenth century with the decline of the silk and shawl industries. By 1886, an inspector reporting child labor violations noted that fewer children and female minors were working in Nîmes than ever before, due to Nîmes' decline as a manufacturing center (Archives Départementales du Gard, M469). Simultaneous with the decline in children's employment opportunities came compulsory education and child labor laws.

As a consequence of these social and economic changes-and doubtless of changes in attitudes toward fertility limitation and knowledge about it - the perceived and real costs of children to the Nimois household rose and the benefits of children declined between 1850 and $1914 .^{\mathrm{s}}$ The occupational bases for high fertility foundered because children could not bring in a wage as they could in coalmining or textile towns (see Haines, 1979; Tilly, 1979). And the relative availability of white collar or at least shop work, in combination with educational and child labor laws, kept children in schools and out of the labor force (Gillis, 1974:61, 77; Kett, 1977:5, 169; Moch, 1981). Consequently, it is reasonable to infer that the family in Nîmes had good reason for making different fertility decisions in 1900 than fifty years earlier (see Easterlin, 1978). Decreased birth rates and low marital fertility at the turn of the century reflect the evolution of fertility decisions in Nîmes.

Low birth rates in Nîmes offer few insights into declining fertility, however, due to the nature of Nîmes' economy and the relatively late period on which this study focuses. Rather, the value of information about Nîmes lies in its use for understanding the role of migrants in this regime of low nuptiality and low fertility. I have gone to the 1906 census lists for answers to these questions: Were migrants the servants and solitary young workers in Nîmes? Were they more likely to be single than native-born Nimois? What can specific migrant groups tell us about migration's impact on urban demographic patterns?

\section{The Data}

The nominal census lists are a particularly appropriate source for these questions.

${ }^{5}$ For a sensitive and informed treatment of noneconomic factors influencing fertility changes, see Ackerman, 1979:37-40, 61-68. 
First, they list individually all members of the population except people in institutions-prisoners and soldiers living in barracks, for example (Ministère du Travail, 1908:2). Consequently, census lists provide more complete information on the urban population than other sources for migration data in France such as marriage records, apprenticeship contracts, voting rolls, and hospital records. Moreover, the French census for the year 1906 lists the commune of birth for each individual so the historian can distinguish native-born Nimois from migrants. Philippe Pinchemel, who was one of the first French historians to employ census lists, summarizes the advantages of the source.

The nominal lists are the only document which present demographic and social phenomena while conserving them in their true milieu which is the commune; only from these lists can social reality be mapped in its actual location ("implantation") (1957:21).

As a record of migratory movements in turn-of-the-century France, the 1906 census lists are an unparalleled document (see Dupeux, 1973). Yet they have drawbacks as a source. Census lists only give a snapshot of the population at a single time and yield no direct information about when, by what processes, or under what circumstances the migrant arrived in the city. They are also subject to errors in reporting, particularly to errors in age reporting (see van de Walle, 1974).

The 1906 census lists were copied from census forms filled in for each individual at the household (the bulletin individuel) (Biraben, 1962:309; Ministère du Travail, 1908:3; van de Walle, 1974:24). The census lists are therefore a copy of householders' information and as such are subject to copying error (van de Walle, 1974:24). The communes then sent the individual bulletins to Paris where they served as a base for machine-tallied aggregate statistics (Biraben, 1963;310; van de Walle, 1974:24). Theoretically, the information included on the lists is identical for all communes in France because the census list forms were identical in format throughout the country (Ministère du Travail, 1908:3, 24).

The lists for the year 1906 included the following information for each individual: address, family name, first name, year of birth, commune of birth, relationship to household head, occupation, and employer (cf. Reddy, 1975). Marital status was not included on the nominal census lists that year. Individuals were grouped by household, which were in turn listed by address. I drew from the census of Nîmes a sample of individuals in 5 percent of the households, a total of 3,601 individuals in 1,082 households.

In order to investigate nuptiality patterns, I relied by necessity on measures of the currently married. Because marital status was not listed, it was inferred conservatively from relationship to household head/household position. People who were co-residing with spouses were coded as currently married (whether they were head of household, daughter, sonin-law, etc.) regardless of relationship to head of household. The vast majority of married males (98 percent) were household heads and the vast majority of married females (93 percent) were listed as spouses, but a few married people were child, child-in-law, parent, or other relative of household head. Servants were coded as not currently married, as were most other men and women without spouse present, even if children were present in the household. Because I was only able to identify currently married, it was impossible to measure the Singulate Mean Age of Marriage (which requires sure identification of the ever-married), $\mathrm{I}_{\mathrm{m}}$, or the percent single at ages 45-49-all standard measures of nuptiality. 
Marital status was inferred with some confidence from these data because household relationship information is complete and very detailed in the 1906 census lists from Nîmes. The census intructions were emphatic as to the explicit nature of information desired in the column "situation par rapport au chef de ménage:"

Indicate in this column the position of each individual in relation to the household of which he is a part, that is, indicate whether he is the head of it or one of its members, whether he belongs as a relative by blood or by marriage, or merely as a paid employee or servant (Ministère du Travail, 1908:24).

More important, the directions were followed. With few exceptions, the precise relationship of each individual to the household head is specified (relationship to head of household is missing in 8 of 2,040 cases of individuals $15-40$ years old). Table 1 lists household position for people ages 15 to 49 not currently married, by origin and sex. The majority in each category are household heads and children of the household head. Relatives are primarily siblings of the household head, followed by niece or nephew, mother-in-law, cousin, grandchild, and non-specified relative. Only the motherin-law is likely ever to have been married, and she may be widowed, divorced, separated, or deserted.

TABLE 1. DETAILED HOUSEHOLD POSITION OF PEOPLE NOT CURRENTLY MARRIED. AGES 15-49 BY SEX AND ORIGIN, NÎMES, 1906.

\begin{tabular}{|c|c|c|c|c|}
\hline & \multicolumn{2}{|c|}{ Males } & \multicolumn{2}{|c|}{ Females } \\
\hline & Natives & Migrants & Natives & Migrants \\
\hline Head of Household & 9 & 32 & 8 & 22 \\
\hline Living with Relatives/Others & 4 & 7 & 5 & 14 \\
\hline Living Alone & 5 & 25 & 3 & 8 \\
\hline Child & 78 & 42 & 67 & 25 \\
\hline Child & 78 & 40 & 67 & 25 \\
\hline Foster Child & $*$ & 2 & 0 & $\bullet$ \\
\hline Other Relatives & 9 & 9 & 17 & 11 \\
\hline Sibling/Sibling-in-Law & 6 & 3 & 10 & 8 \\
\hline Nephew/Niece & 1 & 2 & 3 & 2 \\
\hline Cousin & 0 & 2 & $*$ & $*$ \\
\hline Grandchild & 1 & 1 & $*$ & $\mathbf{0}$ \\
\hline Daughter-in-Law & 0 & 0 & $*$ & 0 \\
\hline Mother-in-Law & $\mathbf{0}$ & 0 & 2 & $\mathbf{0}$ \\
\hline Uncle & * & 0 & 0 & $\mathbf{0}$ \\
\hline Unspecified Relative & * & 1 & 1 & 1 \\
\hline Non-relatives & 4 & 17 & 8 & 42 \\
\hline Servant & 2 & 7 & 7 & 36 \\
\hline Lodger & 1 & 7 & $*$ & 3 \\
\hline Worker/Apprentice/Employee & * & 2 & $*$ & 1 \\
\hline Nun/Priest & $\mathbf{0}$ & 0 & 0 & 1 \\
\hline Friend & $*$ & 1 & 0 & $\bullet$ \\
\hline \multirow[t]{3}{*}{ Other } & $\mathbf{0}$ & 0 & 0 & * \\
\hline & $100 \%$ & $100 \%$ & $100 \%$ & $100 \%$ \\
\hline & 279 & 134 & 345 & 273 \\
\hline
\end{tabular}

"Less than .5 percent, $\mathrm{N}=1$. 
Many people coded as not currently married were not related to the household head; and among these, servants were most important numerically. Other "nonrelatives" were lodgers, although lodgers and boarders played a relatively minor role in Nîmes (Moch, 1981), or workers living with the employer's family. A few were nuns or friends of the family. Although it is impossible to know for certain that servants were currently single, several factors suggest that it is most accurate to code them as single. First, historians Abel Chatelain and Theresa McBride have confirmed the primacy of domestic work as the single migrant female's avenue of entry into the city (McBride, 1976: 34-37; Chatelain, 1969). Live-in domestic service was incompatible with marriage from both the servant's and employer's point of view (McBride, 1976:88). Moreover, the age of servants in Nîmes suggests that most were single: over half were less than twenty-five years old and over three-quarters were under thirty-five (see Table 2). Migrants-the vast majority of servants-were particularly young: 58 percent were between 14 and 25 years old. The mean age of (first) marriage for women wed in Nîmes in 1906 was 26.9 , so women under 25 were often single. Available information on servants' marriages also suggests that they married late (McBride, 1976:87). Finally, the census was based on habitual residence on the night of 3-4 March, 1906 (Ministère du Travail, 1908:3). As a consequence, it reveals whether urban people were living as married or single people. The model of urban migration is based upon the de facto living situation of migrants in the city, regardless of the possibility of a spouse living elsewhere.

Detailed information on household position justifies the coding of servants and other urban residents without spouse present as not currently married because
TABLE 2. AGE OF SERVANTS BY ORIGIN, NÎMES, 1906.

\begin{tabular}{|c|c|c|c|c|}
\hline & & Natives & Migrants & Total \\
\hline \multirow[t]{13}{*}{ Age } & $0-14$ & 0 & 0 & 0 \\
\hline & $15-19$ & 7) & 21) & 18 \\
\hline & $20-24$ & $23 J$ & 37 & 34 \\
\hline & $25-29$ & $23)$ & 14 & $16)$ \\
\hline & 30-34 & $10)$ & & 6 \\
\hline & $35-39$ & $10)$ & 7 & 7 \\
\hline & $40-44$ & 13 & & 10 \\
\hline & $45-49$ & $13)$ & 2 & \\
\hline & & 0 & 2 & \\
\hline & $55-59$ & $0)$ & 1 & 1) \\
\hline & $60-64$ & 0 & 1 & \\
\hline & $65-69$ & $0)$ & 1 & $1)$ \\
\hline & $\begin{array}{l}70 \text { or } \\
\text { older }\end{array}$ & 0 & & 0 \\
\hline Total & & $99 \%$ & $100 \%$ & $99 \%$ \\
\hline $\mathbf{N}$ & & 30 & 112 & 142 \\
\hline
\end{tabular}

household position data are very detailed. But this choice does carry a bias: inferred marital status is likely to exaggerate the size of the unmarried population. Given the household positions of the unmarried population, this exaggeration is more likely to distort data on the migrant population than the native one. As a consequence, any bias in the interpretation of the data works in favor of the urban migration model, which posits that migrants are disproportionately single.

\section{Migrants in Nîmes}

Given the urban migration model of city populations, I expected migrants in Nîmes to account for the majority of its servants, solitary young men, and female household heads. That is, I expected mi- 
grants to be disproportionately represented among the segments of society least likely to be currently married. I was not disappointed: a full 85 percent of Nîmes' servants were migrants from outside town, and migrants dominated the positions of solitary householder and female household head. ${ }^{\circ}$

Although migrants were most of Nîmes' servants and solitaries, it did not follow that migrants were less likely to be married than native-born Nimois. Quite the contrary. Migrants were much more likely to be married than people born in Nîmes. A conservative figure puts the proportion of men currently married at 66 percent for migrant males between the ages of 15 and 49 and a mere 42 percent for males born in Nîmes. Figures for female nuptiality are of greater interest for their implications about relative fertility. Of women in their childbearing years (15-49) 53 percent of the women born outside Nîmes and 40 percent of the Nîmesborn were currently married. The figures

${ }^{6}$ Of the solitary householders, 62 percent were migrants; of the female household heads, 60 percent were migrants. for women aged 20 to 44 , the most active childbearing years in Nîmes, are 56 percent for migrants and 45 percent for Nimoises. In fact, a greater proportion of migrants than native women were married at practically every age between 15 and 49. Table 3 gives the figures by age.

These figures jarred my assumptions about the link between migration and nuptiality. More precisely they present a stern challenge to my underlying assumption that because migrants were likely to be servants and young journeymen, they were less likely to be married relative to native-born city people. This assumption was based upon the finding that elsewhere a sizeable proportion of servants is correlated with low nuptiality in urban areas.' In order to discern the social patterns which may help explain the nuptiality differentials, I compared the family position along with the marital status of native and

'Knodel and Maynes, 1976:150-151, 157. Knodel and Maynes did not make the same assumption; they compared female nuptiality of natives and migrants in Berlin and Frankfurt in 1885. In Berlin, native-born women were less likely to be single at ages 45-49; in Frankfurt there was no difference in proportion single.

TABLE 3. PROPORTION CURRENTLY MARRIED BY SEX AND ORIGIN, NÎMES, 1906.

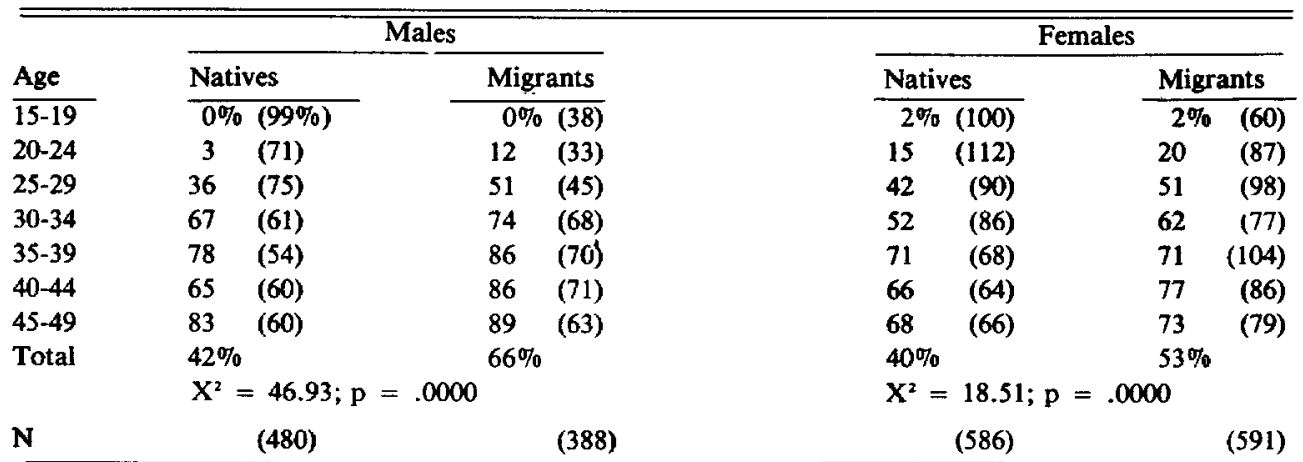

Note: Chi square statistic applies to total only. 
migrant adult women, reasoning that this would identify unmarried people in a meaningful way. Among migrant women (over the age of 14), servants and female household heads accounted for most of the unmarried people (64 percent), although some were living with their relatives or with parents. Among Nîmesborn women, on the other hand, the majority of unmarried were living with their parent(s) (67 percent), and a large proportion (17 percent) were living with a sibling, uncles and aunts, or other relatives. The celibate daughters far outnumbered servants, despite the importance of servant work for women of this age. ${ }^{8}$ Most of the single male natives also lived with their parents (73 percent). Again, unmarried sons living at home outnumbered the celibate migrant males. Nearly a third of the native-born adults (over 14) were unmarried and living at home with their parents (43 percent of the males and 25 percent of the females). The household positions of native and migrant young people are summarized in Table 4.

'About 10 percent of the women in Nimes aged 15-49 worked as servants and about 20 percent of the migrant women at these ages were so employed. Of the unmarried migrant women ages $15-29$, over 40 percent were servants (Moch, 1979:184, 207-208).
As one might expect, these patterns varied over the life course. More men and women, native and migrant, were married as they grew older-proportions married rose sharply at the age of twenty and continued to increase until the age of forty. Celibacy is particularly important under the age of 25 for women, when the great majority of the native-born singles were at home with their parents and the majority of single migrant women were servants. Yet celibacy and living at home was an important pattern for the native-born Nimois into their middle thirties as well. Between the ages of 25 and 34, a full 39 percent of the males and 34 percent of the females born in Nînes were single and were living with their parent(s). For people over the age of 35 , patterns of nuptiality and family role are more similar than at younger ages, although they are confounded by the undocumented role of widowhood, desertion, and divorce.

\section{Fertility}

Although the urban migration model is based upon differential marriage patterns for natives and migrants rather than differential fertility, the child-bearing patterns of native-born urban women and migrant women could be very different and affect urban fertility patterns. For example, women from rural areas could continue rural patterns of relatively high

TABLE 4. HOUSEHOLD POSITION OF PEOPLE NOT CURRENTLY MARRIED BY SEX AND ORIGIN, AGES 15-49, NÎMES, 1906.

\begin{tabular}{|c|c|c|c|c|}
\hline & \multicolumn{2}{|c|}{ Males } & \multicolumn{2}{|c|}{ Females } \\
\hline & Natives & Migrants & Natives & Migrants \\
\hline Head of Household & $9 \%$ & $32 \%$ & $8 \%$ & $22 \%$ \\
\hline Child & 78 & 42 & 67 & 25 \\
\hline Relative & 9 & 9 & 17 & 11 \\
\hline Non-relative & 4 & 17 & 8 & 42 \\
\hline Total & $100 \%$ & $100 \%$ & $100 \%$ & $100 \%$ \\
\hline $\mathrm{N}$ & 279 & 134 & 345 & 273 \\
\hline
\end{tabular}


fertility while living in the city. On the other hand, female migrants may marry later than female natives and they may bear fewer children as a result. There are suggestions from a number of sources that migrant women did, in fact, marry late. Theresa McBride's research on domestic servants suggests that the service work so popular among migrant women caused them to delay marriage (1976:87). Information about women from three New Hampshire towns analyzed by Thomas Dublin indicates that migrant women married later (1979). Moreover, the average age of women marrying for the first time in Nimes in 1906 was 26.6 for migrant women and 24.9 for Nimoises.

Unfortunately, it is nearly impossible to discern whether migrant women bore more or fewer children than native-born women in Nîmes. ${ }^{9}$ First, turn-of-the-century birth records in Nîmes are closed to researchers, so they have not been analyzed by birthplace of mother; differential birthrates for native and migrant women cannot be calculated. Second, even this information would not necessarily serve as an answer, because a search through small town and village birth records reveals that women living in the city often came home to their parents' for childbirth

'The only source which might explicitly address the question of migration's impact upon fertility is the individual bulletins from the 1906 census, which I have not seen. These bulletins posed questions about number of children born (surviving and deceased) to each individual. The information, analyzed by father's occupation and by department, was published in the Statistique des familles in 1912 (Ministère du Travail). According to this report, manuscripts of the detailed tables by department were conserved (presumably in the national archives) and some information about parents' birthplace--at least that of father-may be included. There is no indication that the individual bulletins have been conserved (Ministère du Travail, 1912:1).
(Moch, 1979:272). Consequently, an unknown proportion of children were born to migrant women outside the city. Third, child:woman ratios calculated from the census are unreliable because children were undercounted in the censuses of this period in Southern France (van de Walle, 1974:151). Moreover, between 19 and 21 percent of the children born in Nîmes between 1900 and 1907 were placed with wetnurses outside the city, and it is impossible to discern whether Nîmes-born women or migrant women were more likely to put their children out to nurse (Ville de Nîmes, 1901-1906). The census of Nîmes shows a nearly identical number of children in the home for migrant and native wives (1.47 children per migrant wife, 1.50 per native wife). Thus, the information available for Nîmes, albeit meager, in no way indicates that native and migrant fertility was significantly different.

\section{Household Composition}

The perception of migrants as disproportionately unmarried has been based on their visibility as single servants and workers, people peripheral to the urban family. Given the importance of marriage to the migrant population, it is appropriate to look at the kinds of households and families formed by migrants. One would anticipate that they would form the majority of solitary households and living groups which did not include a nuclear family group (such as siblings without parents or two unrelated people). Likewise, migrants may have been less likely than natives to form an extended family because their relatives were less likely to be in Nîmes. Michael Anderson found that young migrants were less likely than natives to live with their families, and that young married migrants were less likely to live with parents for the simple reason that their parents were not present (Anderson, 1971a:52, 54). 
TABLE 5. HOUSEHOLD STRUCTURE BY ORIGIN OF HOUSEHOLD HEAD, NÎMES, 1906.

\begin{tabular}{lcc}
\hline & $\frac{\text { Native }}{12 \%}$ & $\frac{\text { Migrant }}{15 \%}$ \\
Solitary & 4 & 5 \\
No Family & & \\
$\quad$ Not Nuclear) & 66 & 67 \\
Single Family & 18 & 14 \\
Extended/Multiple & $100 \%$ & $101 \%$ \\
Total & 455 & 599 \\
N & & \\
\hline
\end{tabular}

The structure of all households of the city is listed in Table 5; households headed by people of all ages are included because the living group, not marital status, is in question. Household structure information comes from the 5 percent sample of households in Nîmes. Structure was coded based on the detailed census information on the relationship of each individual to the head of household (see Data section, pp. 73-76). Migrants are somewhat more likely than natives to head solitary households, but the difference is only three percentage points. Migrants are only slightly more likely to head "no family" households (siblings without parents, unrelated people living together, etc.). Native-born Nimois are more likely to head extended families (and in a few cases multiple families) but this difference is one to four percentage points only.

There are differences in the structure of households headed by native-born Nimois and by migrants; and they are the differences one would logically expect. Yet these are differences of degree rather than kind: the great majority of households both of natives ( 66 percent) and migrants (67 percent) are simple nuclear families, as in many other towns (Anderson, 1971a: 44; 1972:200, 222; Katz, 1975:221; Moch, 1979:319).

\section{Migrant Groups}

This comparison of migrants with native- born Nimois involved the very general categories of people born in Nîmes and those born elsewhere. Consequently, migrants include not only young servants and laborers, but people who fit into very different social and economic categories and who may have been more likely to be married. For example, migrants so defined include (a) people from other large cities, such as government bureaucrats, businessmen and their families, and more frequently, (b) people from nearby villages who were likely to be long established residents of Nîmes. A quarter of the migrants in Nìmes belong to this category; they had come from the arrondissement of Nîmes which has a radius of about forty kilometers. In one sense, these general categories are particularly appropriate because they do not cater to the stereotype of the migrant as poor country bumpkin and "marginal" man in social and economic terms. ${ }^{10}$ On the other hand, the interest in comparing migrants with natives lies partly in knowing specifically what kind of migrant-from what kind of home town and familyplayed what role in urban society. Moreover, it was not high-level bureaucrats and migrants from virtually suburban villages who changed the face of Europe in the nineteenth century. "It is rather the migrants who left rural villages and small towns that most changed the patterns of population concentration. It follows that this last kind of migrant is of the greatest interest to historians and historical demographers. Equally important is the fact that migrants from small towns and

${ }^{10}$ See Handlin, 1951; Chevalier, 1973; Park, 1928. for examples of this view of the migrant. For another view, see Akerman, 1977.

"For the view that movement from nearby towns was crucial, see Anderson, 1971b. 
villages inform historians' images and ideas about who migrants were and how they behaved. For this reason, it is particularly appropriate to focus on small town and village migrants here.

The strategy I have chosen for examining particular kinds of migrants is to investigate individual migrant groups from Nîmes' mountainous hinterland living in Nîmes. I have gathered information on the home areas as well as on the migrants. This allows me to link the demographic patterns, economy, and culture of the home town, and the history of migration between the home town and Nîmes, with the urban lives of migrants from these areas. I chose the home towns on the basis of the visibility of migrant streams from those sending areas to Nîmes. Specifically, I went through the census sample to find the areas which sent the most people to Nîmes, considering their size and distance from the city. The biggest senders by these criteria were two towns in the Catholic Lozère. Because Protestants were central to the society and economy of turn of the century Nîmes, I also chose the most important Protestant sending area by the same criteria. Once the three towns were chosen, information was gathered from the census on the total population in Nîmes from each one.

Two migrant streams originated in the Lozère. They came from a village and a small town on the railroad line constructed along the eastern border of the Lozère in the late $1860 \mathrm{~s}$. The first is ninety-nine kilometers north of Nîmes by road; the second is one hundred fortyeight kilometers from Nîmes. Villefort, the village, declined drastically after the railroad connected it with lower Languedoc. The small town Langogne thrived, however, as an exporter of beef and timber. Both Villefort and Langogne sent men and women from some of their poorest families to Nîmes. Those from
Villefort were most likely to be children of agriculteurs, and those from Langogne were likely to be children of unskilled and semiskilled laborers and poor artisans (Moch, 1979:160-163). Fertility declined in both little towns between 1840 and 1906; both probably had lower fertility than the interior villages of the Lozère. Nevertheless, the staunchly Catholic Lozère was the highest fertility area of France in 1906, and the birth rate in both towns was high relative to that of Nîmes (Ministère du Travail, 1912:13-21; Moch, 1979:356-357). The companion strategy to high fertility in the Lozere was out-migration. Indeed, after 1851 the Lozère lost a greater proportion of its people through emigration than any other department of France (Pitié, 1971:9-92, 113, 143, 159). ${ }^{12}$ In sum, the migrants from Villefort and Langogne joined recently formed migration streams between their home town and Nîmes. In the city, the men were employed primarily as railroad, semiskilled and unskilled workers, although some were skilled and white collar workers. Most employed women were servants.

A third migrant stream originated on the edge of the Protestant Cévennes mountains ninety-three kilometers northwest of Nimes in the small town of Le Vigan. Connections between Le Vigan and Nîmes were also founded in the bureaucratic connections joining units of the (a) Catholic church, (b) Protestant community, and (c) French government. Consequently, it is no surprise that migrants include children of Le Vigan's elite and middle-class families as well as children of peasants and laborers. The fertility of Le Vigan was low relative to fertility

${ }^{12}$ For a discussion of the links between high fertility and migration, see, for example, Berkner and Mendels, 1978. 
levels in its mountainous hinterland and to the fertility of the Lozerean towns. Like the Lozerean towns, though, Le Vigan saw a substantial fertility decline in the last half of the nineteenth century and considerable out-migration, particularly at the turn of the century. The migrants from Le Vigan, then, continued a long tradition of connections with Nîmes. In the city, most of the men worked as skilled and white collar workers and the women, when they were employed, worked in the garment industry as well as in service. Some belonged to the urban bourgeoisie.

Differences among the home towns and migrant groups lead me to certain expectations. Because the Lozereans were primarily from laboring and agricultural families, and because they were relatively new to the city as a group, it is reasonable to expect that many of them were young single servants and workers. Although many of the migrants from Le Vigan may have been young single workers, they were likely to include more older Viganais who married and settled in Nîmes. Consequently, it is reasonable to anticipate that the Lozerean's levels of nuptiality would be relatively low.

In fact, members of all three migrant groups were more likely to be unmarried than the total migrant population-only about 54 percent of the men and 43 per- cent of the women were married in contrast with 66 percent and 53 percent of all migrant men and women, respectively. But the groups themselves had very similar levels of nuptiality. Moreover, the patterns of nuptiality by age were similar for the numbers of each group. Before the age of twenty-five, nearly all were single. Between twenty-five and thirty-four, the pattern changed and about 60 percent of the men and 45 percent of the women were married, excluding the group from the village of Villefort. The percentage of married men from Villefort may be low because this group was least able to afford marriage: they were more likely than men from Le Vigan or Langogne to be unskilled and semi-skilled workers in Nîmes and to be sons of agriculteurs. The relative lack of opportunity in Villefort may account for the high proportion of married women from that village in Nîmes. That is, women may have been particularly likely to stay in the city to marry because returning home was unattractive. This speculation is borne out by Villefort's marriage records (Moch, 1979: 111-114). After the age of thirty-five, the vast majority of all three groups was married. Table 6 lists the nuptiality figures for the migrant groups.

Although nuptiality patterns and levels were similar, the identity of the unmarried varied from group to group for men and

TABLE 6. PROPORTION CURRENTLY MARRIED BY SEX AND ORIGIN, MIGRANT GROUPS, NÎMES, 1906.

\begin{tabular}{|c|c|c|c|c|c|c|}
\hline \multirow[b]{2}{*}{ Age } & \multicolumn{3}{|c|}{ Males } & \multicolumn{3}{|c|}{ Females } \\
\hline & Langogne & Villefort & Le Vigan & Langogne & Villefort & Le Vigan \\
\hline $15-24$ & $0 \%$ & $0 \%$ & $6 \%$ & $6 \%$ & $6 \%$ & $12 \%$ \\
\hline $25-34$ & 57 & 33 & 69 & 49 & 71 & 45 \\
\hline $35-49$ & 70 & 68 & 83 & 60 & 60 & 57 \\
\hline Total & $54 \%$ & $52 \%$ & $56 \%$ & $40 \%$ & $49 \%$ & $40 \%$ \\
\hline$N$ & 28 & 33 & 61 & 70 & 57 & 110 \\
\hline
\end{tabular}


TABLE 7. HOUSEHOLD POSITION OF PEOPLE NOT CURRENTLY MARRIED BY SEX AND ORIGIN, MIGRANT STREAMS, AGES 15-49, NÎMES, 1906.

\begin{tabular}{|c|c|c|c|c|c|c|}
\hline & \multicolumn{3}{|c|}{ Males } & \multicolumn{2}{|c|}{ Females } & \multirow[b]{2}{*}{ Le Vigar } \\
\hline & Langogne & Villefort & Le Vigan & Langogne & Villefort & \\
\hline Head of Household & $46 \%$ & $38 \%$ & $7 \%$ & $7 \%$ & $14 \%$ & $18 \%$ \\
\hline Living with Relatives/Others & 31 & 6 & 0 & 5 & 7 & 13 \\
\hline Living Alone & 15 & 31 & 7 & 2 & 7 & 5 \\
\hline Child & 46 & 13 & 67 & 12 & 7 & 44 \\
\hline Relatives & 0 & 18 & 11 & 9 & 17 & 13 \\
\hline Sibling/Sib-in-Law & 0 & 6 & 7 & 2 & 7 & 3 \\
\hline Nephew/Niece & $\mathbf{0}$ & 6 & 4 & 0 & 3 & 5 \\
\hline Grandchild & $\mathbf{0}$ & 0 & 0 & 2 & 0 & 2 \\
\hline Mother-in-Law & $\mathbf{0}$ & 0 & 0 & 0 & 7 & 3 \\
\hline Unspecified Relative & 0 & 6 & 0 & 5 & 0 & $\mathbf{0}$ \\
\hline Non-relatives & 8 & 31 & 15 & 71 & 62 & 27 \\
\hline Servant & 8 & 25 & 4 & 71 & 59 & 20 \\
\hline Worker/Apprentice/Employee & 0 & 6 & 7 & 0 & 3 & 2 \\
\hline Nun/Priest & 0 & 0 & 4 & 0 & 0 & 5 \\
\hline Total & $100 \%$ & $100 \%$ & $100 \%$ & $99 \%$ & $100 \%$ & $102 \%$ \\
\hline $\mathrm{N}$ & 13 & 16 & 27 & 42 & 29 & 66 \\
\hline
\end{tabular}

women. Single men from the Lozère usually were household heads, even though some were living with their parents or their employer's family. By contrast, a substantial majority of single males from Le Vigan lived with their parents. Most single women from the Lozère lived as domestic servants, but the majority of unmarried women from Le Vigan lived with their parents or other relatives. Others were servants. Table 7 summarizes these patterns.

What is the value of information about specific migrant groups in Nîmes? Does it shed any light on urban nuptiality patterns? On one hand, a focus on migrant groups confirms the urban migration model. A relatively small proportion of women in the migrant streams were married; and this is due, at least in part, to the important role played by domestic service, particularly for women from the Lozère. The fact that people in the migrant streams were less likely to be mar- ried than the total migrants in Nîmes suggests that married migrants were often part of the large group of people from the immediate vicinity. They were likely to have settled in the city early in life and to have been very similar, in terms of life patterns, to people born in the city. This speculation is corroborated by high marriage figures for migrants from Nîmes' immediate hinterland: 72 percent of the men and 60 percent of the women from the arrondissement of Nîmes were married in 1906. Household position confirms the importance of servant employment among female newcomers from village and small towns, and the existence of traditions of domestic service for particular groups.

On the other hand, some aspects of the groups contravene hypotheses that the migrant, even the small town or rural migrant, was single. The proportion of Viganais over 15 who had moved to Nîmes with their parent(s) suggests that 
families as well as single people moved to urban areas. I will return to this point. Moreover, the similar nuptiality patterns of the three migrant streams implies that a certain proportion of migrants-even from rural areas-were married prior or subsequent to migration. I infer from the breakdown of nuptiality by age group that marriage after migration and continued residence in the city may have been common. Reconstructions of the movements and relationships among women from the Lozère show that often an elder sister would move to Nîmes, work as a servant, and marry, and that young sisters would then follow and find work as servants. In light of the current understanding of chain migration, a process by which established members of a migrant stream help newcomers, this is not surprising (Tilly, 1978b). The broad inference to be made from group nuptiality patterns is that many migrants married and became permanent residents of the city-perhaps in record proportions during the period of rapid urbanization after 1850. (Unfortunately, the number of households formed by the migrant streams is too small to provide useful fertility or household composition information.)

\section{Conclusion}

Unmarried urban adolescents and adults fell into three kinds of living arrangements in Nimes: they (a) lived with people to whom they were not related, primarily as servants, (b) headed their own households, often living alone, or (c) lived with parent(s) or other relatives. Most single people in the first two categories were migrants, those in the third category were largely natives-and the third category was most important numerically. Although these findings must be viewed with caution because marital status was inferred from household position, they are suf- ficiently striking to suggest that a refinement of our images is in order-images both of the migrant and of the native in the European city.

Perhaps the long historical tradition of urban servant work for women and journeymen training for artisans accounts for a focus on the temporary nature of urban residence for the migrant. There are indications that temporary migration was less important to young people at the end of the nineteenth century than before, and that it was replaced by permanent settlement in the city..$^{13}$ Certainly, then, the relative importance of temporary urban residence to migration patterns calls for reassessment, particularly for Europe in the late nineteenth century.

The fact that migration streams have been initiated by single people may account for an emphasis on singles' migration. Yet clearly, people came to the city with their families, even to non-textile cities such as Nimes. This is reflected in the significant proportion of migrant men and women who were living with their parents in Nîmes. Although a far greater proportion of natives than migrants were living with parents, a substantial proportion of migrants (43 percent of the men and 25 percent of the women) lived in their parents' household. This phenomenon was particularly striking among the Viganais, for whom family migration was clearly important.

Assumptions about the role of urbanborn young people in demographic patterns may require a more substantial adjustment. Knodel and Maynes speculate that servant migrants may only partly account for low urban nuptiality and, indeed, celibacy among native urbanites

${ }^{13}$ These come from many quarters, such as Abel Chatelain, 1976:1105-1106; Lequin, 1977:267; and Gillis, 1974:51-52. 
may be a second major factor. The linking of Europe's demographic transition, including the fertility decline and change in the European marriage patterns described by Hajnal, with urbanization and industrial growth has encouraged demographic historians to look to cities as areas of "modern" early and more universal marriage (Hajnal, 1953; Knodel, 1977:356-357; Knodel and Maynes, 1976: 129-130). Unexpectedly low urban nuptiality has quite naturally led scholars to turn to the migrant-the young single worker, soldier and servant-for an explanation. Knodel and Maynes found that the presence of highly visible single migrants (servants) was highly correlated with low nuptiality in German cities. ${ }^{14}$ Yet native-born urban people also had good reasons to remain single, perhaps even more so than migrants from outside the city. Their celibacy was rooted in their dependencies, obligations, and opportunities.

It is quite possible that unmarried people stayed at home because they were more dependent on parents than ever before. Schooling had a much greater role to play in job and career options than fifty years earlier, particularly in a town like Nimes, where commercial and other white collar employment was relatively important. The post-primary school facilities for both men and women expanded at the turn of the century with growth of the lycée, collège de filles, and normal schools. At this time stenography attracted more students than any other vocational course offered by the Bourse du Travail (Annuaire du Gard, 1880; Brugier, 1925:138; Fermaud, 1953; Guide du Gard, 1907). Moreover, the decrease in jobs for children and young people which

\footnotetext{
${ }^{14} \mathrm{Knodel}$ and Maynes found that the ratio of servants to total women aged 15-29 was significantly related to female celibacy at ages $20-24$ and $45-49$ (1976:150-151).
}

accompanied deindustrialization in Nîmes meant prolonged and exacerbated dependence on parents. As a consequence of both trends, it is arguable that young people in Nîmes were likely to stay at home longer in 1906 than ever before. (See Gillis, 1974:61; Katz, 1975:256, 374-378; Kett, 1977:5, 451-152, 169; Moch, 1981.)

The general obligation to care for parents may have been particularly great for urban people, both because they had been supported by their parents and because they had relatively few siblings with which to share that responsibility. On the other hand, parents of migrants often were cared for by children who stayed at home. I infer from the proportion of celibate native Nimois who stayed with their parents into middle age that the story of Hélène Donzel was not unique. Mademoiselle Donzel lived with her aging widowed father, brother, and nephew. Old Monsieur Donzel was retired, and the younger men worked as government officials at the Préfecture in Nîmes. Despite the family's relative prosperity and high standing in the Protestant community, they had no live-in servant, so it appears that Hélène did much if not all the cleaning, cooking, and shopping. When Monsieur Donzel died, Hélène was forty-three years old. Within months, she wed a twice-married merchant from the Aveyron and left Nîmes.

Opportunity may have kept more children at home than ever before at the turn of the century. In an urbanizing nation, opportunity concentrated in the cities; the decline of artisanal training gave the urban-born one less reason to leave home. The net result of both trends may have been to center existing opportunity in the town of origin and to decrease the chances for city people of leaving town (Anderson, 1971a:59). ${ }^{15}$

'The single Nimois who left town for other opportunities were not registered in the census. With- 
The migrants and natives of Nîmes do not corroborate the urban migration model. This may be because the character of migration to cities changed during the nineteenth century, as I suggest above. It may also be because Nîmes in 1906 was in some ways a special case. This is true insofar as grape overproduction reduced wine prices at the turn of the century to the general detriment of the city's economy. As a result, the market for servants and for other single laborers was probably depressed in 1906, but by how much it is impossible to tell. Finally, Nîmes may not confirm the model of urban migration because the information about Nîmes allows a more complete and clear view of migrants' marriage patterns. ${ }^{16}$ Regardless of how these three explanations-time, place, and method-balance out, findings from this city suggest that migrants are by no means solely responsible for low urban nuptiality.

Moreover, these findings confirm the centrality of low levels of nuptiality to urban demographic structure, because they suggest the importance of unmarried people in the city population. Marriage patterns separate natives from migrants more than the kinds of families in which they live and perhaps more than the number of children they bear. Although the evidence from Nîmes is an insufficient base for a judgment of the impact of internal migration on fertility, the household evidence

out a detailed scan of the census of Marseille and Montpellier, for example, it is impossible to know if many Nîmes-born unmarried people left home.

${ }^{16}$ Sasaki (1977) likewise found rates of nuptiality for migrants in the city of Takayama, Japan to be higher than those of natives in the period 1773-1871. I am grateful to Ronald Toby for alerting me to this finding. Sasaki used sect affiliation registers (Shümon aratame chö), which, like the 1906 French census, give birthplace for individuals. from the census clearly suggests that marriage, not numbers of children, divides the reproductive from the non-reproductive elements of urban society. The phenomenon to be explained is not nativemigrant differences per se, but urban celibacy.

This investigation into an apparently adequate explanation for urban demographic patterns has yielded an ironic result. By pressing the native-migrant distinction with information about individuals and about migrant groups, that distinction has been severely weakened in favor of others. Important differences became apparent among migrants, in this case (a) among those from various kinds of home towns, and (b) among those who moved as single young people, as families, and those who married and settled in the city subsequent to migration. This serves as a reminder that migration is but one feature which distinguishes urban people, who in Nîmes were also divided by class, occupation, and religious culture. Indeed, the rich variety of migrants in Nîmes has undermined the characterization of the migrants as a uniform, separate category.

\section{BIBLIOGRAPHY}

\section{Ackerman, Evelyn B.}

1979 Village on the Seine. Ithaca, N.Y.: Cornell University Press.

Åkerman, Sune

1977 "Swedish Migration and Social Mobility: The Tale of Three Cities." Social Science History 1:178-209.

Anderson, Michael

1971a Family Structure in Nineteenth Century Lancashire. Cambridge: Cambridge University Press.

1971b "Urban Migration in Nineteenth-Century Lancashire: Some Insights Into Two Competing Hypotheses." Annales de démographie historique 13-26.

1972 "Household Structure and the Industrial Revolution: Mid-Nineteenth Century Pres- 
ton in Comparative Perspective." In Peter Laslett and Richard Wall, eds., Household and Family in Past Time, 215-235. Cambridge: Cambridge University Press.

1976 "Marriage Patterns in Victorian Britain: An Analysis Based on Registration District Data for England and Wales." Journal of Family History 1, 1:55-79.

Annuaire du Gard

1880

Archives Départementales du Gard Report of Labor Violations, M469.

Berkner, Lutz and Franklin Mendels

1978 "Inheritance Systems, Family Structure, and Demographic Patterns in Western Europe, 1700-1900." In Charles Tilly, ed., Historical Studies of Changing Fertility, 209-223. Princeton: Princeton University Press.

Biraben, Jean Noel

1962 "Inventaire des listes nominatives de recensement en France." Population 18:305-328.

Braun, Rudolf

1978 "Early Industrialization and Demographic Change in the Canton of Zurich." In Charles Tilly, ed., Historical Studies of Changing Fertility, 289-334. Princeton, NJ: Princeton University Press.

Brugier, Victorien

1925 La Bourse du Travail a Nîmes. Nî̀mes: Imprimerie l'Idéale.

Chatelain, Abel

1969 "Migrations et domesticité feminine urbaine en France, XVIIIe siècle-XXe siecle." Revue d'histoire économique et sociale 47:506-528.

1976 Les migrants temporaires en France de 1800 à 1914. Lille: Presses Universitaires de Lille.

Chevalier, Louis

1973 Laboring Classes and Dangerous Classes. New York: Fertig.

Coale, Ansley

1969 "The Decline of Fertility in Europe from the French Revolution to World War II." In Samuel J. Behrman, Leslie Corsa, Jr., and Ronald Freedman, eds., Fertility and Family Planning, 3-24. Ann Arbor: University of Michigan Press.

Corbin, Alain

1975 Archaism et modernité en Limousin au XIXe siècle, 1845-1880. Paris: Rivière.

Dugrand, Raymond

1963 Villes et campagnes en Bas-Languedoc. Paris: Presses Universitaires Françaises.
Dublin, Thomas

1979 "The Social Origins and Consequences of Urban Migration: Migration and Nonmigrants from Three New Hampshire Towns." Paper presented at the annual meetings of the Social Science History Association, Cambridge, Mass., November.

Dupeux, Georges

1973 "Immigration urbaine et secteurs économiques: l'example de Bordeaux au début du XXe siécle." Annales du Midi 85:209-220.

Easterlin, Richard

1978 "The Economics and Sociology of Fertility: A Synthesis." In Charles Tilly, ed. Historical Studies of Changing Fertility, 57-135. Princeton: Princeton University Press.

Fermaud, Alice

1953 "La lycée de jeunes filles de Nîmes." Revue économique de la Chambre de Commerce du Nîmes-Uzès-Le Vigan 4, 35:16-18.

Garden, Maurice

1970 " $L$ 'attraction de Lyon à la fin de l'ancien régime." Annales de démographie historique:205-220.

Gillis, John

1974 Youth and History: Tradition and Change in European Age Relations, 1770-Present. New York: Academic Press.

Guide du Gard

1907

Haines, Michael

1979 Fertility and Occupation: Population Patterns in Industrialization. New York: Academic Press.

Hajnal, John

1953 "Age at Marriage and Proportions Marrying." Population Studies 7:111-136.

1965 "European Marriage Patterns in Perspective." In D. V. Glass and D. E. C. Eversley, eds., Population in History: Essays in Historical Demography. Chicago: Aldine Publishing Co.

Handlin, Oscar

1951 The Uprooted. New York: Grosset and Dunlap.

Katz, Michael

1975 The People of Hamilton, Canada West. Cambridge: Harvard University Press.

Kett, Joseph

1977 Rites of Passage. New York: Basic Books.

Knodel, John and Mary Jo Maynes

1976 "Urban and Rural Marriage Patterns in Imperial Germany." Journal of Family History 1:129-168. 
Knodel, John

1977 "Town and Country in 19th-Century Germany: A Review of Urban-Rural Differentials in Demographic Behavior." Social Science History 1:356-382.

Lamorisse, René

1975 La Population de la Cévenne Languedocienne. Montpellier: Paysan du Midi.

Laslett, Peter

1977 "Characteristics of the Western Family Considered Over Time." Journal of Family History 2, 2:89-116.

Lequin, Yves

1977 Les ouvriers de la région lyonnaise. Lyon: Presses universitaires de Lyon.

LeRoy Ladurie, Emmanuel

1966 Les paysans du Languedoc. Paris: S.E.V.P.E.N.

Levine, David

1977 Family Formation in an Age of Nascent Capitalism. New York: Academic Press.

McBride, Theresa

1976 The Domestic Revolution. New York: Holmes and Meier.

Mazel, Elie

1887 "Statistique démographique de la ville de Nînes comparée (1876-1888)." Mémoires de l'Académie de Nîmes, Sér. 7, 10:213266.

Ministère du Travail et de la Prévoyance Socialé

1908 Résultats statistiques du recensement général de la population, Tome I. Paris: Imprimerie Nationale.

1912 Statistique des familles en 1906. Paris: Imprimerie Nationale.

Moch, Leslie Page

1979 "Migrants in the City: Newcomers to Nîmes, France at the Turn of the Century." Unpublished Ph.D. Dissertation, University of Michigan.

1981 "Adolescence and Migration to Nimes, 1906." Social Science History 5, forthcoming.

Park, Robert

1928 "Human Migration and the Marginal Man." American Journal of Sociology 33:881-893.

Pinchemel, Philippe

1957 Structures sociales et dépopulation rurale dans les campagnes Picardes de 1836 à Pitié, Jean 1936. Paris: Armand Colin.

1971 Exode rural et migrations intérieures en France. Poitiers: Norois.
Reddy, William

1975 "Family and Factory: French Linen Weaving in the Belle Epoque." Journal of Social History 9:102-112.

Sasaki, Yoichiro

1977 "Edo jidai toshi jinkō iji noryoku ni tsuite: Hida Takayama no keikenatai ni motozuku ichi jikken no kekka." In Shakai Keizaishi Gakkai, ed., Atarsahii Edo jidai shizō o motomete, 135-152. Tōkoyō: Toyo Keizai Shinpōsha.

Sharlin, Allan

1977 "Historical Demography as History and Demography." American Behavioral Scientist 21:245-262.

1978 "Natural Decrease in Early Modern Cities: A Reconsideration." Past and Present 79: 126-138.

Statistique générale

1848 Industrie: Résultats généraux de l'enquête effectué pendant l'année 1848. Paris: Imprimerie Nationale.

Tilly, Charles

1978a Historical Studies of Changing Fertility. Princeton: Princeton University Press.

1978b "Migration in Modern European History." In William McNeill and Ruth Adams, eds., Human Migration, Patterns and Policies, 48-72. Bloomington: Indiana University Press.

Tilly, Louise A.

1979 "Occupational Structure, Women's Work and Demographic Change in Two French Industrial Cities, Anzin and Roubaix, 1892-1906." In Jan Sundlin and Erik Soderlund, eds., Time, Space and Man, 107-132. Atlantic Highlands, NJ: Humanities Press.

Tilly, Louise A. and Joan Scott

1978 Women, Work and Family. New York: Holt, Rinehart and Winston.

van de Walle, Etienne

1974 The Female Population of France in the Nineteenth Century. Princeton: Princeton University Press.

Ville de Nîmes Bulletin Municipal 1904-1908.

Wrigley, E. Anthony

1971 Population and History. New York: McGraw Hill. 